\title{
Degree of implementation and satisfaction in food companies with the International Food Standards (IFS) and British Retail Consortium (BRC) certifications on the Canary Islands
}

\author{
Grau de implementação e satisfação nas empresas alimentares com as certificações International \\ Food Standards (IFS) e British Retail Consortium (BRC) nas Ilhas Canárias \\ Acoraida Fontaine ${ }^{1}$, António Raposo ${ }^{2}$, Rafael Millán ${ }^{1}$, Esther Sanjuán ${ }^{1}$, Conrado Carrascosa ${ }^{1}$ \\ ${ }^{1}$ Department of Animal Pathology and Production, Bromatology and Food Technology, Faculty of Veterinary, Universidad de \\ Las Palmas de Gran Canaria, 35413 Arucas, Las Palmas, Spain. \\ ${ }_{2}^{2}$ CBIOS (Research Center for Biosciences and Health Technologies), Universidade Lusófona de Humanidades e Tecnologias, \\ Campo Grande 376, 1749-024 Lisboa, Portugal. \\ Email: antonio.raposo@ulusofona.pt
}

\begin{abstract}
The aim of this study was to assess the degree of the implementation and satisfaction of quality certificates in agrifood industries using structured interviews based on International Food Standards (IFS) and British Retail Consortium (BRC), which have become most relevant in the food industry due to growing consumer demands, and, given the emergence of several food crises, quality assurance schemes have become increasingly popular in agrifood businesses.

Questionnaires were sent to fifty-seven companies. Two structured questionnaires were divided into five parts with nineteen and fifteen questions, respectively. All the companies were interviewed by an electronic questionnaire sent by email, but companies were first called by telephone to inform them about the study. Interviews started with a question about the number of employees in the company, followed by another question about the kind of certificate that the company held. At the time this research was conducted on the Canary Islands, nineteen companies had IFS and twenty did not, but had other certificates. Eighteen companies did not answer the questionnaire.

The representative survey results clearly demonstrated that the overall evaluation of IFS/BRC was positive. Food manufacturers generally perceived the IFS as a useful instrument for assuring product safety. The companies without IFS were satisfied with their certification and, although their perception of IFS was positive, they thought it was very expensive and it was better to continue with the certificate they had.
\end{abstract}

Keywords: agrifood; BRC; Canary Islands; IFS; questionnaire.

\section{Resumo}

O objectivo deste estudo foi avaliar o grau de implementação e satisfação dos certificados de qualidade em indústrias agroalimentares, utilizando entrevistas estruturadas com base em International Food Standards (IFS) e British Retail Consortium (BRC), que se tornaram mais relevantes na indústria alimentar devido ao aumento das demandas dos consumidores, e dado o surgimento de várias crises alimentares, os esquemas de garantia de qualidade tornaram-se cada vez mais populares nos negócios agroalimentares.

Foram enviados questionários para cinquenta e sete empresas. Dois questionários estruturados foram divididos em cinco partes com dezenove e quinze perguntas, respectivamente. Todas as empresas foram entrevistadas por um questionário eletrónico enviado por e-mail, tendo sido inicalmente contactadas por telefone de forma a serem informadas. As entrevistas começaram com uma pergunta sobre o número de funcionários da empresa, seguida de outra questão sobre o tipo de certificado que a empresa possuía. No momento em que esta investigação foi realizada nas Ilhas Canárias, dezesseis empresas tinham IFS e vinte não, mas possuíam outros certificados. Dezoito empresas não responderam ao questionário. Os resultados representativos da aplicação dos questionários demonstraram claramente que a avaliação geral do IFS/ BRC foi positiva. Os produtores alimentares geralmente percepcionam o IFS como um instrumento útil para garantir a segurança do produto. As empresas sem IFS ficaram satisfeitas com a certificação e, embora a sua percepção do IFS tenha sido positiva, pensou-se que seria muito dispendioso e seria melhor continuar com o certificado que possuíam.

Palavras-chave: agroalimentar; BRC; IFS; Ilhas Canárias; questionário. 


\section{Introduction}

The importance of quality in the food sector has significantly grown in recent decades because of increasing consumer expectations, government regulations and expanding market competition. Therefore, agrifood companies have increasingly pursued quality management practices ${ }^{1}$.

The Canary Islands (Spain) are an outlying area in which the tertiary sector is the main driving force of its economy. Industry is limited and represents around $7-8 \%$ of the regional Gross Domestic Product, which centres on manufacturing agrifood and processing sectors ${ }^{2}$.

We can differentiate between two kinds of industry on the Canary Islands; one covering domestic demand and the other involving exports ${ }^{3}$. The companies that serve the domestic market are normally small- or mediumsized with medium or low levels of technology, which are usually enough to cover the region's needs. Export companies are larger and more technologically complex. The agrifood industry, along with its associated cold and manufacturing industry, particularly stands out ${ }^{3}$.

The agricultural sector's activity on the Canary Islands is linked mainly to two large export crops: bananas and tomatoes ${ }^{4}$. In 2013, the largest volume of Canarian exports went to the European Union (excluding Spain), which accounted for $63.5 \%$ of the total exports, followed by African countries with $27.8 \%$. The main commercial destination among non-EU European countries and Eastern Europe was Switzerland, followed by Russia and Norway, while Hong Kong is the top destination for Canarian exports in the Asia-Pacific and Oceania region.

The main customer for North America, Central America and the Caribbean was the USA, followed by Cuba and Canada ${ }^{3}$. In South America, Brazil, and Ecuador and Venezuela (to a lesser extent), stood out. Trade with the Middle East focused especially on Israel, the United Arab Emirates and Saudi Arabia ${ }^{3}$.

The IFS Food Standard is a recognised Global Food Safety Initiative (GFSI) standard for auditing food manufacturers ${ }^{5}$. Its focus lies in food safety, and also in the quality of processes and products. It affects food processing companies and those companies that pack loose food products ${ }^{5}$.

The IFS Food Standard applies when products are "processed" or when a product contamination hazard arises during primary packing. This standard is important for all food manufacturers, especially for those that produce private labels, as it contains many requirements

\section{Introdução}

A importância da qualidade no sector alimentar tem crescido significativamente nas últimas décadas devido ao aumento das expectativas dos consumidores, dos regulamentos governamentais e da crescente concorrência no mercado. Portanto, as empresas agroalimentares têm procurado cada vez mais práticas de gestão da qualidade ${ }^{1}$.

As Ilhas Canárias (Espanha) são uma região periférica em que o sector terciário é a principal força motriz de sua economia. A indústria é limitada e representa cerca de $7-8 \%$ do Produto Interno Bruto regional, que se centra nos sectores agroalimentares e de processamento ${ }^{2}$.

Podemos diferenciar entre dois tipos de indústria nas ilhas Canárias; um cobre a demanda doméstica e o outro envolve as exportações ${ }^{3}$. As empresas que atendem ao mercado doméstico são normalmente de pequeno ou médio porte com níveis médios ou baixos de tecnologia, que geralmente são suficientes para cobrir as necessidades da região. As empresas de exportação são maiores e mais tecnologicamente complexas. A indústria agroalimentar, juntamente com a indústria do frio e manufactura associada são as que se destacam ${ }^{3}$.

A actividade do sector agrícola nas Ilhas Canárias está ligada principalmente a duas grandes culturas de exportação: bananas e tomates ${ }^{4}$. Em 2013, o maior volume de exportações das Canárias foi destinado à União Europeia (excluindo Espanha), que representou $63,5 \%$ das exportações totais, seguido por países africanos com $27,8 \%$. O principal destino comercial entre os países europeus não pertencentes à União Europeia e a Europa Oriental foi a Suíça, seguido da Rússia e da Noruega, enquanto Hong Kong é o principal destino das exportações Canárias na região Ásia-Pacífico e Oceania.

O principal cliente para a América do Norte, América Central e Caribe foram os Estados Unidos da América, seguido de Cuba e Canadá 3. Na América do Sul, Brasil, e Equador e Venezuela em menor medida, destacaram-se. O comércio com o Médio Oriente concentrou-se especialmente em Israel, Emirados Árabes Unidos e Arábia Saudita ${ }^{3}$.

O IFS é reconhecido pela Global Food Safety Initiative (GFSI) como um padrão para a auditoria de produtores alimentares ${ }^{5}$. O seu foco é a segurança alimentar e também a qualidade dos processos e produtos. Refere-se às empresas de processamento de alimentos e às empresas que embalam produtos alimentares soltos ${ }^{5}$.

O padrão alimentar IFS aplica-se quando os produtos são "processados" ou quando surge um risco de contaminação do produto durante a embalagem primária. Este padrão é importante para todos os fabricantes de 
related to complying with customer specifications ${ }^{5}$. This standard supports production and marketing departments and their efforts to brand safety and quality. IFS Food Standard has been developed with the full active involvement of certification bodies, retailers, the food industry and food service companies.

In 2002, German retailers worked together on the Quality Assurance Board of the EHI Retail Institute and developed the IFS. Since then, major retailers have subscribed to the system, thus the IFS has become most relevant in international business relations, especially in the European food industry ${ }^{6}$.

The majority of these retailers no longer accept suppliers without an IFS certificate and, consequently, the IFS has become one of the most important quality assurance schemes. In view of the IFS' increasing acceptance, the French Fédération des Entreprises du Commerce et de la Distribution (FCD) joined efforts in 2003 to produce an updated version of the standard. Currently property rights are shared by the Hauptverband Desdeutschen Einzelhandels (HDE) and the FCD ${ }^{6}$.

One of the main reasons why the IFS is continuously proliferated and developed is the rising number of retailer-owned private labels in the European food industry. The IFS is a neutral instrument based on third-party audits that can lower costs and improve quality at the same time. For this reason, the standard has been widely accepted in German and French retail sectors, and has moved towards setting a certification standard for not only private labels, but also for manufacturer brands ${ }^{6}$. In effect, the IFS has largely replaced the International Organization for Standardization (ISO) standard in the European food industry.

The IFS is divided into four chapters ${ }^{5}$ :

\section{The IFS Protocol}

The Catalogue of Requirements

The Requirements for Certification Bodies and Auditors

\section{The IFS Report}

The main IFS chapter, called the "Catalogue of Requirements", is based on the structure of ISO 9001, and its main technical chapters are quality system management, management responsibility, resource management and product realisation, measurements, analyses and improvements. The similarity between the IFS and ISO 9001 was one of the main contemplated considerations while developing the new standard. The IFS also depends mostly on the BRC's evaluation system and structure, which also refer to ISO $9001^{6}$.

Nevertheless, a closer look reveals that both standards, ISO 9001 and the IFS, are also characterised by alimentos, especialmente para aqueles que produzem rótulos privados, pois contém muitos requisitos relacionados ao cumprimento das especificações do cliente ${ }^{5}$. Este padrão apoia os departamentos de produção e marketing e contribui para a segurança e qualidade da marca. O padrão alimentar IFS foi desenvolvido com o pleno envolvimento activo de organismos de certificação, retalhistas, indústria alimentar e empresas de serviços de alimentação.

Em 2002, os retalhistas alemães trabalharam juntos no Conselho de Garantia da Qualidade do EHI Retail Institute e desenvolveram o IFS. Desde então, os principais retalhistas inscreveram-se no sistema, pelo que o IFS tornou-se mais relevante nas relações comerciais internacionais, especialmente na indústria alimentar europeia ${ }^{6}$.

A maioria destes retalhistas já não aceita fornecedores sem um certificado IFS e, consequentemente, o IFS tornou-se um dos mais importantes esquemas de garantia de qualidade. Em vista da crescente aceitação do IFS em 2003, a Federação Francesa de Empresas do Comércio e da Distribuição (FCD) juntou esforços para produzir uma versão actualizada do padrão. Actualmente, os direitos de propriedade são compartilhados pela Hauptverband Fromutschen Einzelhandels (HDE) e pelo $\mathrm{FCD}^{6}$.

Uma das principais razões pelas quais o IFS está continuamente proliferado e desenvolvido é o crescente número de rótulos privados de retalho na indústria alimentar europeia. O IFS é um instrumento neutro baseado em auditorias de terceiros que podem reduzir os custos e melhorar a qualidade ao mesmo tempo. Por esse motivo, o padrão foi amplamente aceite nos sectores retalhistas alemão e francês, e avançou para a definição de um padrão de certificação para não apenas marcas particulares, mas também para marcas fabricantes 6 . Com efeito, o IFS substituiu em grande parte o padrão International Organization for Standardization (ISO) na indústria alimentar europeia.

O IFS está dividido em quatro capítulos ${ }^{5}$ :

O Protocolo IFS

O Catálogo de Requisitos

Os Requisitos para Organismos de Certificação e Auditores

\section{O Relatório IFS}

O principal capítulo do IFS, chamado "Catálogo de Requisitos", é baseado na estrutura da ISO 9001 e os seus principais capítulos técnicos são gestão do sistema de qualidade, responsabilidade de gestão, gestão de recursos e realização do produto, medições, análises e melhorias. A semelhança entre o IFS e a ISO 9001 foi 
a remarkable difference. Unlike the ISO standard, the IFS is distinguished by several industry-specific regulations; e.g., the introduction of various food product categories and regulations that are particularly important for the food industry (medical examinations, staff hygiene, analysing drinking water, pest control, and so forth). The standard also includes various K.O. (Knock Out) criteria that are important mainly for food safety. These criteria must be fulfilled if a certificate is to be assigned. By meeting the requirements of standards, a company can be certified at the foundation level or the higher level ${ }^{6}$.

This study aimed to assess the degree of satisfaction, advantages and disadvantages, and the implementation of quality certificates IFS and BRC into agrifood industries located on the Canary Islands (Spain), by means of a structured questionnaire.

\section{Material and methods}

This research was conducted to assess the degree of implementing quality certificates into agrifood industries. It conducted a survey using a structured questionnaire to assess the perceptions of the advantages and disadvantages of the IFS and its degree of implementation and satisfaction. The selection of a survey-based research strategy seemed logical to conduct a confirmatory or explanatory study that used well-defined concepts and models. We further validated the final questionnaire by using the pilot questionnaire to ask two operations managers ${ }^{6,7}$.

The authors are available to supply the reader with a copy of the questionnaires, upon request.

\section{Participants}

The sectors chosen for this study were water, ice and drinks $(n=6)$, alcoholic drinks $(n=8)$, meat $(n=9)$, dairy products $(n=4)$, cheeses $(n=4)$, cereals and pastas $(n=3)$, bakery $(n=11)$, coffee $(n=6)$, flours and gofio (roasted corn/wheat flour) $(\mathrm{n}=2)$, sauces and mojos (Canary sauces) $(\mathrm{n}=1)$, and packaged fruits and vegetables $(n=3)$ (total=57) (Figure 1). Of the 57 initial companies, 39 companies operated in the food sector, 11 were small-sized ( $<50$ employees), 25 were medium-sized $(50-250$ employees) and three were large-sized $(>250$ uma das principais considerações contempladas ao desenvolver o novo padrão. O IFS também depende principalmente do sistema e estrutura de avaliação do BRC, que também se refere à ISO $9001^{6}$.

No entanto, um olhar mais atento revela que ambos os padrões, ISO 9001 e IFS, também são caracterizados por uma diferença notável. Ao contrário do padrão ISO, o IFS é distinguido por vários regulamentos específicos da indústria; por exemplo, a introdução de várias categorias e regulamentos de produtos alimentares que são particularmente importantes para a indústria alimentar (exames médicos, higiene do pessoal, análise de água potável, controle de pragas, etc.). O padrão também inclui vários critérios K.O. (Knock Out) que são importantes principalmente para a segurança alimentar. Esses critérios devem ser cumpridos se um certificado for atribuído. Ao atender aos requisitos das normas, uma empresa pode ser certificada no nível de fundação ou no nível superior ${ }^{6}$.

Este estudo teve como objectivo avaliar o grau de satisfação, vantagens e desvantagens, e a implementação de certificados de qualidade IFS e BRC em indústrias agroalimentares localizadas nas ilhas Canárias (Espanha), através de um questionário estruturado.

\section{Material e métodos}

Esta investigação foi conduzida para avaliar o grau de implementação de certificados de qualidade em indústrias agroalimentares. Aplicou-se um questionário estruturado para avaliar as percepções das vantagens e desvantagens do IFS e o seu grau de implementação e satisfação. A selecção de uma estratégia de investigação baseada em questionário tornou lógica a realização um estudo confirmatório ou explicativo que usasse conceitos e modelos bem definidos. Nós ainda validámos o questionário final, usando o questionário piloto para entrevistar dois gestores de operações ${ }^{6,7}$.

Os autores estão disponíveis para fornecer ao leitor uma cópia dos questionários, mediante solicitação.

\section{Participantes}

Os sectores escolhidos para este estudo foram água, gelo e bebidas $(n=6)$, bebidas alcoólicas $(n=8)$, carne $(\mathrm{n}=9)$, produtos lácteos $(\mathrm{n}=4)$, queijos $(\mathrm{n}=4)$, cereais e massas $(n=3)$, padaria $(n=11)$, café $(n=6)$, farinhas e gofio (milho torrado/farinha de trigo) $(\mathrm{n}=2)$, molhos e mojos (molhos canários) $(\mathrm{n}=1)$ e frutas embaladas e vegetais $(n=3)($ total $=57)$ (Figura 1$)$. Das 57 empresas iniciais, 39 empresas operavam no sector alimentar, 11 eram de pequeno porte ( $<50$ funcionários), 25 eram de médio porte (50-250 funcionários) e três eram de 
employees) ${ }^{1,4}$. The questionnaire was sent to 57 companies, and 39 favourably answered. grande porte (>250 funcionários) ${ }^{1,4}$. O questionário foi enviado para 57 empresas, mas apenas 39 responderam favoravelmente.

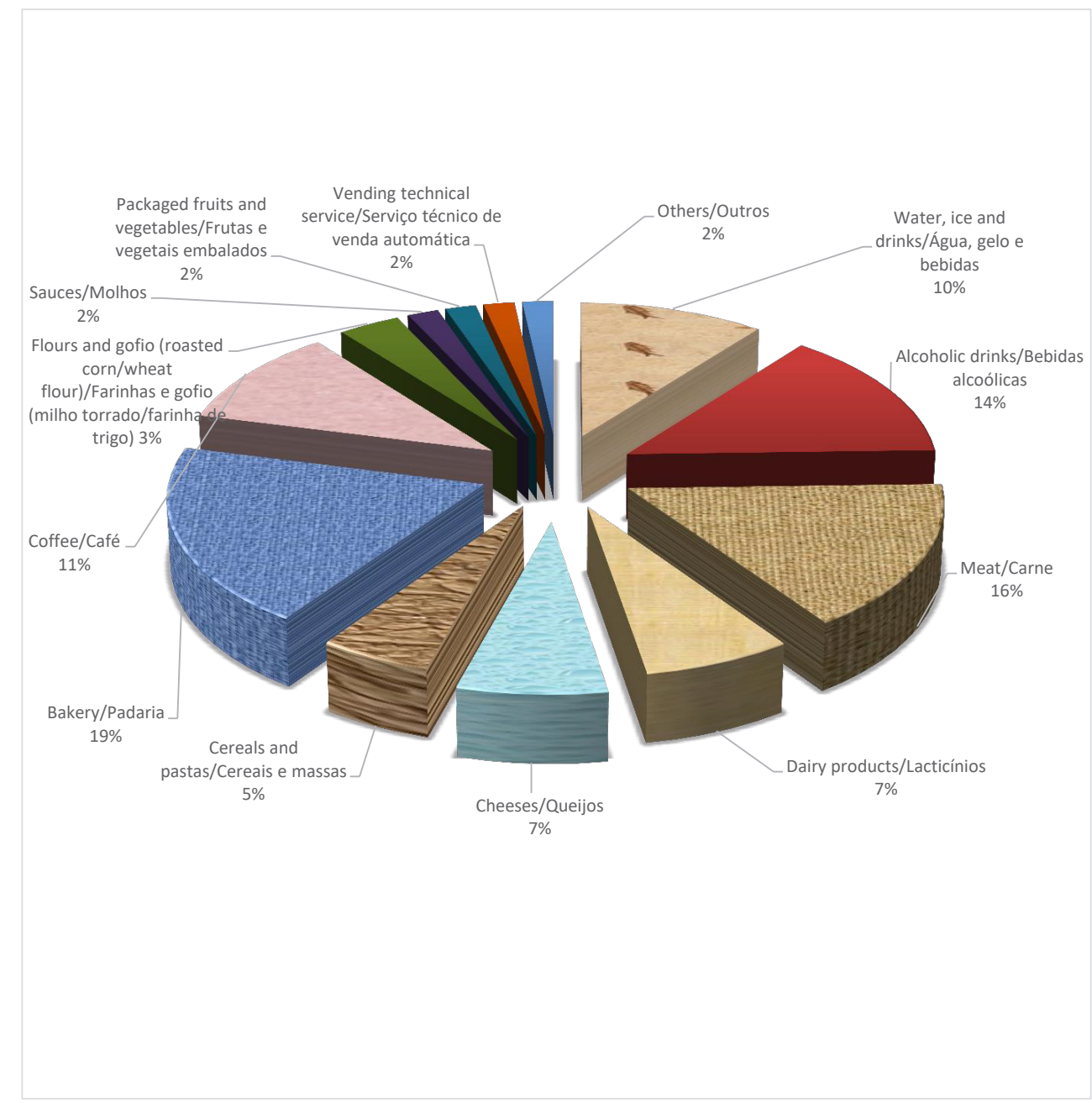

Figure 1/Figura 1 - Percentages (\%) of types of products produced in Canarian food factories Percentagens (\%) dos tipos de produtos elaborados nas fábricas de alimentos nas Canárias

\section{Designing the interview questions}

A structured in-depth interview protocol that followed a Likert-type scale was designed 7 . The Likert scale is one of the most widely used tools by market researchers when they wish to evaluate the opinions and attitudes of a given person or company. The Likert scale assumes that the strength and intensity of the experience is linear. Therefore, it ranges from totally agree to totally disagree by assuming measurable attitudes. Answers can be offered at different measurement levels. There should always be a neutral element for those users who neither agree nor disagree. These surveys are frequently used to measure quality. The obtained data were grouped on an Excel (Microsoft, USA)

\section{Projectando as perguntas de entrevista}

Um protocolo de entrevista estruturado em profundidade que seguiu uma escala de tipo Likert foi projectado ${ }^{7}$. A escala Likert é uma das ferramentas mais utilizadas pelos investigadores de mercado quando desejam avaliar as opiniões e atitudes de uma determinada pessoa ou empresa.

A escala de Likert assume que a força e a intensidade da experiência são lineares. Portanto, esta escala vai de totalmente concordar em totalmente discordar ao assumir atitudes mensuráveis. As respostas podem ser oferecidas em diferentes níveis de medição. Deve haver sempre um elemento neutro para os entrevistados que não concordam nem discordam. Estas investigações 
spreadsheet and classified after assuming that answers between 4 and 5 were positive, those between 1 and 2 were negative, and those in the middle had been answered as neutral. Tables were prepared with the statistical results shown in the Results section. Questions were grouped into categories according to different criteria to assess companies' perceptions and their awareness of quality certificates. Categories differed if the first questionnaire was completed by those with an implemented IFS, or if the second one was completed by those that had implemented another standard ${ }^{6,8}$.

The first questionnaire included:

- Perceived cost/benefit ratio

- Company owners' perceived information (update from the IFS scheme)

- Perceived auditor's expertise and effectiveness

- Perceived costs of certification

- Degree of satisfaction

The second questionnaire included:

- Perceived knowledge about the IFS or BRC

- Implementation of quality and food safety certificates

- The sector's requirements

- Disadvantages

- Advantages

\section{Interviews}

Thirty-nine companies were interviewed by an electronic questionnaire, which took between 5 and 10 minutes to complete. These questionnaires were sent between January and June 2017. The questionnaire was usually answered by the company's quality manager. Before starting the questionnaire, participants were informed about the purpose of the research, and were assured that their identities would not be revealed ${ }^{6,8}$.

\section{Statistical analysis}

Questions were summarised as frequencies and percentages, which were compared using Fisher's exact test. Statistical significance was set at $p<0.05$. Data were analysed using the R package, version 3.3.1 9 . são constantemente usadas para medir a qualidade.

Os dados obtidos foram agrupados numa folha de Excel e classificados depois de assumir que as respostas entre 4 e 5 eram positivas, as entre 1 e 2 eram negativas e as do meio foram respondidas de uma forma neutral. As tabelas foram preparadas com os resultados estatísticos mostrados na secção Resultados. As perguntas foram agrupadas em categorias de acordo com diferentes critérios para avaliar as percepções das empresas e sua conscientização sobre certificados de qualidade. As categorias diferiram se o primeiro questionário fosse preenchido por aqueles com um IFS implementado, ou se o segundo fosse completado por aqueles que implementaram outro padrão ${ }^{6,8}$.

O primeiro questionário incluiu:

- Taxa de custo / rácio benefício

- Informações percebidas pelos proprietários das empresas (actualização do esquema IFS)

- Experiência percebida pelo auditor e eficácia

- Custos percebidos de certificação

- Grau de satisfação

O segundo questionário incluiu:

- Conhecimento percebido sobre o IFS ou BRC

- Implementação de certificados de qualidade e segurança alimentar

- Requisitos do sector

- Desvantagens

- Vantagens

\section{Entrevistas}

Trinta e nove empresas foram entrevistadas via um questionário eletrónico, que levou entre 5 e 10 minutos para completar. Estes questionários foram enviados entre Janeiro e Junho de 2017. O questionário foi geralmente respondido pelo gestor de qualidade da empresa. Antes de iniciar o questionário, os participantes foram informados sobre o propósito da investigação e foram assegurados que suas as identidades não seriam reveladas ${ }^{6,8}$.

\section{Análise estatística}

As perguntas foram sumarizadas como frequências e percentagens, que foram comparadas usando o teste exacto de Fisher. A significância estatística foi definida em $p<0,05$. Os dados foram analisados usando o pacote $\mathrm{R}$, versão 3.3.19. 


\section{Results and discussion}

\section{Companies with the IFS}

The descriptive results (Table 1) for the variables provided some first impressions of companies' attitudes towards certification schemes. All in all, companies evaluated the IFS positively; $95.0 \%$ of them were generally satisfied with the standard. This is a very positive evaluation compared to other studies that have analysed the acceptance of other schemes with lower evaluation results ${ }^{6,10,11}$. However, only $48.7 \%$ would have implemented the IFS even if it was not required by their retailers

Regarding the IFS, $74.0 \%$ of the companies emphasised that the advantages of the IFS outweighed its disadvantages, which is a higher percentage compared with $70.6 \%$ of the companies in Europe ${ }^{6}$, of which $100 \%$ stated that the IFS provided useful input for operational management compared with $82.2 \%$ of the companies in Europe ${ }^{6}$. Moreover, 58.0\% reported that the IFS improved their relationship with customers versus $51.3 \%$ of the companies in Europe ${ }^{6}$.

Furthermore, $90.0 \%$ of the companies agreed that the IFS essentially contributed to increase food safety, a higher percentage compared with $56.2 \%$ of the companies in Europe ${ }^{6}$, and $79.0 \%$ noted that the IFS improved food safety management compared with $64.3 \%$ of the companies in Europe ${ }^{6}$.

Regarding IFS costs, $90.0 \%$ generally considered them to be the most important factor. However, $84.0 \%$ of the companies believed that it entailed a lot of paperwork and $42.0 \%$ believed that companies spent a very long time on the certification process compared with $77.0 \%$ of the companies in Europe ${ }^{6}$. In addition, $74.0 \%$ believed that operational expenses were justified by the benefits gained compared with $43.0 \%$ of the companies in Europe ${ }^{6}$, and only $37.0 \%$ of companies had to hire more staff to be certified.

The interpretation of the results showed that certification costs were not as relevant as expected, and instead the "perceived cost/benefit ratio" factor turned out to be the most important one. The standard owner's communication and information and the auditor's perceived expertise were more important for assessing the certification standard than the perceived certification costs.

\section{Resultados e discussão}

\section{Empresas com o IFS}

Os resultados descritivos (Tabela 1) para as variáveis proporcionaram algumas primeiras impressões das atitudes das empresas em relação aos esquemas de certificação. Em suma, as empresas avaliaram positivamente o IFS; 95,0\% estavam geralmente satisfeitas com o padrão. Esta é uma avaliação muito positiva em comparação com outros estudos que analisaram a aceitação de outros esquemas com menores resultados de avaliação $6,10,11$. No entanto, apenas $48,7 \%$ teriam implementado o IFS mesmo que faltassem os requisitos de um retalhista.

Em relação ao IFS, 74,0\% das empresas enfatizaram que as vantagens compensaram as desvantagens, sendo uma percentagem maior em comparação com 70,6\% das empresas na Europa ${ }^{6}$, dos quais 100\% declararam que o IFS forneceu inputs úteis para a gestão operacional em comparação com 82,2\% das empresas na Euro$\mathrm{pa}^{6}$. Além disso, $58,0 \%$ relataram que o IFS melhorou a sua relação com os clientes contra $51,3 \%$ das empresas na Europa ${ }^{6}$.

Além disso, 90,0\% das empresas concordaram que o IFS contribuiu essencialmente para aumentar a segurança alimentar, uma percentagem maior em comparação com 56,2\% das empresas na Europa ${ }^{6}$ e 79,0\% observaram que o IFS melhorou a gestão da segurança alimentar em comparação com $64,3 \%$ das empresas na Europa ${ }^{6}$.

No que diz respeito aos custos relacionados com o IFS, $90,0 \%$ considerou, geralmente, como o factor mais importante. No entanto, $84,0 \%$ das empresas acreditavam que isso implicava muita papelada e $42,0 \%$ acreditavam que as empresas passaram muito tempo no processo de certificação em comparação com $77,0 \%$ das empresas na Europa ${ }^{6}$. Além disso, $74,0 \%$ acreditavam que as despesas operacionais foram justificadas pelos benefícios obtidos em comparação com $43,0 \%$ das empresas na Europa ${ }^{6}$, e apenas $37,0 \%$ das empresas tiveram que contratar mais funcionários para serem certificadas.

A interpretação dos resultados mostrou que os custos de certificação não eram tão relevantes quanto o esperado e, em vez disso, o factor de "rácio custo presumido/ benefício" revelou-se o mais importante. O padrão da comunicação e informação do proprietário e os conhecimentos presumidos pelo auditor foram mais importantes para avaliar o padrão de certificação do que os custos de certificação presumidos. 


\section{Companies without the IFS}

No publications about making objective comparisons were found in any of the evaluations/items in this part of the study. The results (Table 2) revealed that in the first item "Perceived knowledge about the IFS or BRC", $80.0 \%$ of the companies perceived their current self-checking system as being correct, $90.0 \%$ of the companies knew what the IFS certification consisted of, and $80.0 \%$ of them stated that they obtained updated information on quality and food safety certificates.

A surprisingly large number of companies (75.0\%) acknowledged that they would implement a new food quality and safety system. However, only $50.0 \%$ of those surveyed would choose the IFS as their first option, while $65.0 \%$ of the companies believed that it was a very useful system.

The item "Sector requirements" was very important as it indicated if the market exerted any pressure on food industries by "forcing" them to implement a given quality and/or food safety system. The results were quite clear; $45.0 \%$ of the companies stated No, $15.0 \%$ of them indicated Yes, and $40.0 \%$ of them did not answer this question. These results led us to think that markets had no influence on this sector type ${ }^{12}$ as $45 \%$ of the companies stated "No".

Finally, the interpretation of the results showed that the companies generally perceived more advantages than disadvantages. Among the most important advantages, $75.0 \%$ of the companies recognised that a system like the IFS would allow them to make direct benefits, and $70.0 \%$ believed that their staff would be qualified to successfully pass the certification process. However, $70.0 \%$ of the companies considered it a very costly system, and $50.0 \%$ of them believed it involved too much paperwork ${ }^{13}$.

Our contribution highlights a variety of theoretical starting points for further research to evaluate quality assurance systems in food supply chains. This study also provides initial indications of the positive and negative impacts of certification schemes on food companies' internal processes. In the long run, the success of quality assurance systems, and satisfaction and positive motivations, are important because a scheme with bureaucratic burden will not lead to major quality improvements.

By and large, most companies believed that the IFS had too much bureaucratic burden and those companies without this system thought that it did not match the obtained benefits.

For the question as to whether the companies that were considering implementing the IFS/BRC actually believed it would provide them with more benefits, some

\section{Empresas sem o IFS}

Nenhum artigo sobre como fazer comparações objectivas foi encontrado em nenhuma das avaliações/itens nesta parte do estudo. Os resultados (Tabela 2) revelaram que, no primeiro item "conhecimento presumido sobre o IFS ou BRC", 80,0\% das empresas presumiram que seu sistema de auto-verificação actual era correto, $90,0 \%$ das empresas sabiam em que é que a certificação IFS consistia, e $80,0 \%$ declararam que obtiveram informações actualizadas sobre certificados de qualidade e segurança alimentar.

Um número surpreendentemente grande de empresas $(75,0 \%)$ reconheceu que implementariam um novo sistema de segurança e qualidade alimentar. No entanto, apenas $50,0 \%$ dos entrevistados escolheriam o IFS como sua primeira opção, enquanto $65,0 \%$ das empresas acreditavam que era um sistema muito útil.

$\mathrm{O}$ item "Requisitos do sector" foi muito importante, pois indicava se o mercado exercia pressão sobre as indústrias alimentares, obrigando-as a implementar um determinado sistema de qualidade e/ou segurança alimentar. Os resultados foram bastante claros; $45,0 \%$ das empresas declararam que Não, $15,0 \%$ indicaram Sim e $40,0 \%$ não responderam a esta pergunta. Esses resultados levaram-nos a pensar que os mercados não tiveram influência neste tipo de sector ${ }^{12}$, pois $45,0 \%$ das empresas responderam "Não".

Finalmente, a interpretação dos resultados mostrou que as empresas geralmente percebiam mais vantagens do que desvantagens. Entre as vantagens mais importantes, $75,0 \%$ das empresas reconheceram que um sistema como o IFS lhes permitiria alcançar benefícios directos e $70,0 \%$ acreditavam que a sua equipa seria qualificada para passar com sucesso o processo de certificação. No entanto, $70,0 \%$ das empresas consideraram um sistema muito oneroso, e 50,0\% acreditavam que isso implicava muita papelada ${ }^{13}$.

A nossa contribuição destaca uma variedade de pontos de partida teóricos para investigação adicional de forma a avaliar sistemas de garantia de qualidade nas cadeias de fornecimento de alimentos. Este estudo também fornece indicações iniciais sobre os impactos positivos e negativos dos esquemas de certificação nos processos internos das empresas alimentares. A longo prazo, o sucesso dos sistemas de garantia de qualidade e a satisfação e motivações positivas são importantes porque um esquema com carga burocrática não levará a melhorias de qualidade importantes.

De modo geral, a maioria das empresas acreditava que o IFS tinha muito peso burocrático e que as empresas sem este sistema pensavam que não combinava com os benefícios obtidos. 
Table 1/ Tabela 1 - Results of the questionnaires answered by companies with IFS divided into categories

Resultados dos questionários respondidos por empresas com IFS divididos em categorias.

\begin{tabular}{|c|c|c|c|c|c|c|}
\hline Total $n=19$ & & & & Jão & & $\begin{array}{l}\text { o } \\
\text { r/Não } \\
\text { ndeu }\end{array}$ \\
\hline $\begin{array}{l}\text { Perceived cost/benefit } \\
\text { presumido/benefício }\end{array}$ & $\mathrm{n}$ & $\%$ & $\mathrm{n}$ & $\%$ & $\mathrm{n}$ & $\%$ \\
\hline 1. Improved management/Melhoria na gestão & 19 & 100 & & & & \\
\hline 2. Improved safety/Melhoria na segurança & 17 & 90 & 1 & 5 & 1 & 5 \\
\hline $\begin{array}{l}\text { 3. More transparency in the processes/Mais } \\
\text { transparência nos processos }\end{array}$ & 15 & 79 & 1 & 5 & 3 & 16 \\
\hline 4. Has more advantages/Tem mais vantagens & 14 & 74 & & & 5 & 26 \\
\hline $\begin{array}{l}\text { 5. Has improved the relationship/Melhorou o } \\
\text { relacionamento }\end{array}$ & 11 & 58 & 1 & 5 & 7 & 37 \\
\hline 6. Expenses are justified/As despesas são justificadas & 14 & 74 & 1 & 5 & 4 & 21 \\
\hline 7. Is useful/É útil & 17 & 90 & 1 & 5 & 1 & 5 \\
\hline $\begin{array}{l}\text { 8. Entails too much bureaucracy/Contém muita } \\
\text { burocracia }\end{array}$ & 16 & 84 & 3 & 16 & 3 & 16 \\
\hline $\begin{array}{l}\text { Perceived communication of standard owner/Comunicação } \\
\text { perceptível do proprietário padrão }\end{array}$ & $\mathrm{n}$ & $\%$ & $\mathrm{n}$ & $\%$ & $\mathrm{n}$ & $\%$ \\
\hline $\begin{array}{l}\text { 9. Has up-to-date information via the IFS/Tem } \\
\text { informações actualizadas através do IFS }\end{array}$ & 15 & 79 & 1 & 5 & 3 & 16 \\
\hline $\begin{array}{l}\text { 10. Has up-to-date information via the Internet/Tem } \\
\text { informações actualizadas através da Internet }\end{array}$ & 18 & 95 & & & 1 & 5 \\
\hline $\begin{array}{l}\text { Perceived auditor's expertise and effectiveness/Percepção } \\
\text { da experiência e eficácia do auditor }\end{array}$ & $\mathrm{n}$ & $\%$ & $\mathrm{n}$ & $\%$ & $\mathrm{n}$ & $\%$ \\
\hline $\begin{array}{l}\text { 11. Excellent auditor's work/Excelente trabalho de } \\
\text { auditoria }\end{array}$ & 15 & 79 & 1 & 5 & 3 & 16 \\
\hline 12. Auditor's expertise/Experiência do auditor & 17 & 90 & & & 2 & 10 \\
\hline $\begin{array}{l}\text { 13. Auditor does not know his/her work/O auditor não } \\
\text { conhece o seu trabalho }\end{array}$ & & & 17 & 90 & 2 & 10 \\
\hline $\begin{array}{l}\text { 14. Auditor posed good questions/O auditor apresentou } \\
\text { boas questões }\end{array}$ & 16 & 84 & & & 3 & 16 \\
\hline $\begin{array}{l}\text { 15. Auditor looked for mistakes/O auditor procurou } \\
\text { erros }\end{array}$ & 15 & 79 & 1 & 5 & 3 & 16 \\
\hline 16. Auditor was professional/O auditor foi profissional & 16 & 84 & 2 & 10 & 1 & 5 \\
\hline $\begin{array}{l}\text { Perceived certification costs/Custos de certificação } \\
\text { presumidos }\end{array}$ & $\mathrm{n}$ & $\%$ & $\mathrm{n}$ & $\%$ & $\mathrm{n}$ & $\%$ \\
\hline $\begin{array}{l}\text { 17. Hired more staff to be certified/Contratou mais } \\
\text { funcionários para serem certificados }\end{array}$ & 7 & 37 & 11 & 58 & 1 & 5 \\
\hline $\begin{array}{l}\text { 18. Took a long time to be certified/Levou muito tempo } \\
\text { para ser certificado }\end{array}$ & 8 & 42 & 3 & 16 & 8 & 42 \\
\hline Degree of satisfaction/Grau de satisfação & $\mathrm{n}$ & $\%$ & $\mathrm{n}$ & $\%$ & $\mathrm{n}$ & $\%$ \\
\hline 19. Degree of satisfaction/ Grau de satisfação & 18 & 95 & 1 & 5 & & \\
\hline
\end{tabular}


Table 2/Tabela 2 - Results of the questionnaires answered by companies without the IFS divided into categories

Resultados dos questionários respondidos por empresas sem IFS divididos em categorias

Total $n=20$

Yes/Sim

No/Não

No

answer/Não

respondeu

\begin{tabular}{lllllllll}
\hline Perceived knowledge about IFS or BRC/Conhecimento & $\mathrm{n}$ & $\%$ & $\mathrm{n}$ & $\%$ & $\mathrm{n}$ & $\%$
\end{tabular}

presumido sobre IFS ou BRC

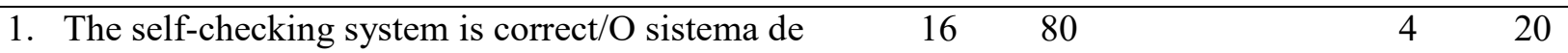
auto-verificação está correcto

2. Knowing what the IFS is/Conhecimento sobre o que $\quad \begin{array}{lllllll}18 & 90 & 1 & 5 & 1 & 5\end{array}$ é o IFS

3. Has up-to-date information via the Internet/Tem $\quad \begin{array}{lllllll}16 & 80 & 2 & 10 & 2 & 10\end{array}$ informações actualizadas através da Internet

Implementing quality and food safety

certificates/Implementação de certificados de qualidade e

segurança alimentar

4. Has thought about implementing a similar system/Pensou em implementar um sistema similar

5. Would choose the IFS as the first option/Escolheria $\quad \begin{array}{lllllll}10 & 50 & 4 & 20 & 6 & 30\end{array}$ o IFS como a primeira opção

6. Implementing this IFS is useful/Implementar este $\quad \begin{array}{lllllll}13 & 65 & 3 & 15 & 4 & 20\end{array}$ IFS é útil

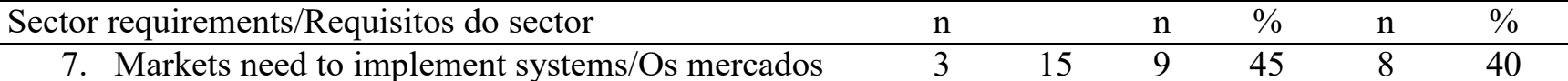
precisam de implementar sistemas

\begin{tabular}{lcccccc}
\hline Disadvantages/Desvantagens & $\mathrm{n}$ & $\%$ & $\mathrm{n}$ & $\%$ & $\mathrm{n}$ & $\%$ \\
\hline 8. It is not useful/Não é útil & 6 & 30 & 9 & 45 & 5 & 25 \\
9. There are other more useful systems/Existem outros & 4 & 20 & 4 & 20 & 12 & 60 \\
$\quad \begin{array}{l}\text { sistemas mais úteis } \\
\text { 10. It is very expensive/É muito dispendioso }\end{array}$ & 14 & 70 & 2 & 10 & 4 & 20 \\
11. It entails plenty of bureaucracy/Implica muita & 10 & 50 & 4 & 20 & 6 & 30 \\
$\quad$ burocracia & & & & & & \\
\hline Advantages/Vantagens & $\mathrm{n}$ & $\%$ & $\mathrm{n}$ & $\%$ & $\mathrm{n}$ & $\%$ \\
\hline $\begin{array}{l}\text { 12. Improved management/Melhoria na gestão } \\
\text { 13. Would bring benefits/Aportaria beneficios }\end{array}$ & 13 & 65 & 2 & 10 & 5 & 25 \\
14. Staff would meet regulations/Os funcionarios & 15 & 75 & 3 & 15 & 2 & 10 \\
$\quad$ cumpririam os regulamentos & 14 & 70 & 2 & 10 & 4 & 20 \\
15. Company would successfully pass/A empresa & 13 & 65 & & & 7 & 35 \\
$\quad$ passaria com sucesso & & & & & & \\
16. More benefit with the IFS/Mais benefícios com o & 10 & 50 & 4 & 20 & 6 & 30 \\
$\quad$ IFS & & & & & &
\end{tabular}


discrepancies appeared as the companies with the IFS considered that the corresponding expenses were justified by the benefits gained. Moreover, some of the companies without the IFS answered Yes, but others answered No.

The results of the surveys with frequencies and percentages (Tables 3 and 4) did not detect any significant difference $(\mathrm{p}<0.05)$ between the surveyed industries according to their size (S, M, L). To perform Fisher's Exact Test, the results of the large- and medium-sized industries were merged to obtain results that fell more in line with the distribution of each company according to its size as there were only two companies in Group L. Nonetheless, the answer for Question 4 (Has IFS/BRC improved safety in food production?) was almost significant $(\mathrm{p}<0.059)$, and it clearly moved towards detecting statistical significance with a larger sample size.
Para a pergunta de saber se as empresas que estavam considerando implementar o IFS/BRC acreditavam que isso thes proporcionaria mais benefícios, surgiram algumas discrepâncias, já que as empresas com o IFS consideravam que as despesas correspondentes eram justificadas pelos benefícios obtidos. Além disso, algumas das empresas sem o IFS responderam Sim, mas outras responderam Não.

Os resultados das investigações com frequências e percentagens (Tabelas 3 e 4) não detectaram diferença significativa $(p<0,05)$ entre as indústrias investigadas de acordo com seu tamanho (S, M, L). Para realizar o Teste Exacto de Fisher, os resultados das indústrias de grande e médio porte foram incorporados para obter resultados que se aproximaram mais da distribuição de cada empresa de acordo com seu tamanho, pois havia apenas duas empresas no Grupo L. No entanto, a resposta para a Pergunta 4 (O IFS / BRC melhorou a segurança na produção de alimentos?) foi quase significativo ( $\mathrm{p}<0,059)$, e moveu-se claramente no sentido de detectar a significância estatística com um tamanho de amostra maior. 
Table 3/Tabela 3 - Companies with the IFS. Statistically significant results $(p<0.05)$ among different companies according to size (L: large), (M: medium), (S: small)

Empresas com IFS. Resultados estatisticamente significativos $(p<0,05)$ entre diferentes empresas de acordo com a dimensão (L: grande), (M: médio), (S: pequeno).

\begin{tabular}{|c|c|c|c|c|}
\hline & \multicolumn{3}{|c|}{ Size/Dimensão } & \multirow[b]{3}{*}{$\mathrm{P}$} \\
\hline & Total & $\mathrm{M}=13 / \mathrm{L}=2$ & $\mathrm{~S}$ & \\
\hline & $\mathrm{N}=19$ & $\mathrm{~N}=15$ & $\mathrm{~N}=4$ & \\
\hline $\mathrm{Q} / \mathrm{P} 1$ & & & & 0.603 \\
\hline 1 & 0 & 0 & 0 & \\
\hline 2 & 0 & 0 & 0 & \\
\hline 3 & 0 & 0 & 0 & \\
\hline 4 & $7(36.8)$ & $5(33.3)$ & $2(50.0)$ & \\
\hline 5 & $12(63.2)$ & $10(66.7)$ & $2(50.0)$ & \\
\hline $\mathrm{Q} / \mathrm{P} 2$ & & & & 0.745 \\
\hline 1 & 0 & 0 & 0 & \\
\hline 2 & $1(5.3)$ & $1(6.7)$ & $0(0.0)$ & \\
\hline 3 & $1(5.3)$ & $1(6.7)$ & $0(0.0)$ & \\
\hline 4 & $6(31.6)$ & $4(26.7)$ & $2(50.0)$ & \\
\hline 5 & $11(57.9)$ & $9(60.0)$ & $2(50.0)$ & \\
\hline $\mathrm{Q} / \mathrm{P} 3$ & & & & 0.833 \\
\hline 1 & 0 & 0 & 0 & \\
\hline 2 & $1(5.3)$ & $1(6.7)$ & $0(0.0)$ & \\
\hline 3 & $3(15.8)$ & $3(20.0)$ & $0(0.0)$ & \\
\hline 4 & $6(31.6)$ & $4(26.7)$ & $2(50.0)$ & \\
\hline 5 & $9(47.4)$ & $7(46.7)$ & $2(50.0)$ & \\
\hline $\mathrm{Q} / \mathrm{P} 4$ & & & & 0.059 \\
\hline 1 & 0 & 0 & 0 & \\
\hline 2 & 0 & 0 & 0 & \\
\hline 3 & $5(26.3)$ & $2(13.3)$ & $3(75.0)$ & \\
\hline 4 & $6(31.6)$ & $6(40.0)$ & $0(0.0)$ & \\
\hline 5 & $8(42.1)$ & $7(46.7)$ & $1(25.0)$ & \\
\hline $\mathrm{Q} / \mathrm{P} 5$ & & & & 1 \\
\hline 1 & 0 & 0 & 0 & \\
\hline 2 & $1(5.3)$ & $1(6.7)$ & $0(0.0)$ & \\
\hline 3 & $7(36.8)$ & $5(33.3)$ & $2(50.0)$ & \\
\hline 4 & $4(21.1)$ & $3(20.0)$ & $1(25.0)$ & \\
\hline 5 & $7(36.8)$ & $6(40.0)$ & $1(25.0)$ & \\
\hline Q/P6 & & & & 0.814 \\
\hline 1 & $1(5.3)$ & $1(6.7)$ & $0(0.0)$ & \\
\hline 2 & 0 & 0 & 0 & \\
\hline 3 & $4(21.1)$ & $3(20.0)$ & $1(25.0)$ & \\
\hline 4 & $10(52.6)$ & $7(46.7)$ & $3(75.0)$ & \\
\hline 5 & $4(21.1)$ & $4(26.7)$ & $0(0.0)$ & \\
\hline $\mathrm{Q} / \mathrm{P} 7$ & & & & 0.449 \\
\hline 1 & 0 & 0 & 0 & \\
\hline 2 & $1(5.3)$ & $1(6.7)$ & $0(0.0)$ & \\
\hline 3 & $1(5.3)$ & $0(0.0)$ & $1(25.0)$ & \\
\hline 4 & $7(36.8)$ & $6(40.0)$ & $1(25.0)$ & \\
\hline 5 & $10(52.6)$ & $8(53.3)$ & $2(50.0)$ & \\
\hline $\mathrm{Q} / \mathrm{P} 8$ & & & & 0.451 \\
\hline 1 & 0 & 0 & 0 & \\
\hline 2 & 0 & 0 & 0 & \\
\hline 3 & $3(15.8)$ & $3(20.0)$ & $0(0.0)$ & \\
\hline 4 & $8(42.1)$ & $7(46.7)$ & $1(25.0)$ & \\
\hline 5 & $8(42.1)$ & $5(33.3)$ & $3(75.0)$ & \\
\hline
\end{tabular}


Q/P9

0.195

1

0

0

0

$1(6.7)$

$0(0.0)$

$1(6.7)$

$2(50.0)$

3 (15.8)

5 (33.3)

$0(0.0)$

$5(26.3)$

8 (53.3)

Q/P10

0

0.276

0

0

0

$0(0.0)$

$2(50.0)$

$1(5.3)$

9 (47.4)

8 (53.3)

7 (46.7)

Q/P11

9 (47.4)

1 0

\section{0}

$1(5.3)$

3 (15.8)

8 (42.1)

7 (36.8)

Q/P12

1
2
3

0

0

2 (10.5)

$10(52.6)$

7 (36.8)

0

1 (6.7)

3 (20.0)

$6(40.0)$

5 (33.3)

0

0

1 (25.0)

1 (25.0)

$2(50.0)$

4

5

Q/P13

11 (57.9)

6 (31.6)

2 (10.5)

0

0

Q/P14

\section{0}

0

2

3 (15.8)

11 (57.9)

5 (26.3)

5

Q/P15

9 (47.4)

6 (31.6)

3 (15.8)

0

$1(5.3)$

5

Q/P16

1

0

2 (10.5)

$1(5.3)$

$10(52.6)$

0

0

2 (13.3)

8 (53.3)

5 (33.3)

0.745

$9(60.0)$

4 (26.7)

2 (13.3)

0

0

0

$0(0.0)$

$0(0.0)$

2 (50.0)

2 (50.0)

0

0

$0(0.0)$

$2(50.0)$

2 (50.0)

2 (50.0)

2 (50.0)

$0(0.0)$

0

0

1

1

1

$0 \quad 0$

0

0

2 (13.3)

$1(25.0)$

$9(60.0)$

$2(50.0)$

$1(25.0)$

4 (26.7)

7 (46.7)

1

$2(50.0)$

1 (25.0)

$1(25.0)$

2 (13.3)

0

0

$0(0.0)$

1 (6.7)

0.814

$6(31.6)$

0

0

$0(0.0)$

$0(0.0)$

$2(50.0)$

$2(50.0)$

Data are frequencies (\%)/Os dados são frequências (\%)

Q/P: Question/Pergunta; Numbers below Q/P represent Likert scale intervals/ Números abaixo de Q/P representam intervalos de escala de Likert 
Table 4/Tabela 4 - Companies without the IFS. Statistically significant results $(p<0.05)$ among different companies according to size (L: large), (M: medium), (S: small)

Empresas sem IFS. Resultados estatisticamente significativos $(p<0,05)$ entre diferentes empresas de acordo com a dimensão (L: grande), (M: médio), (S: pequeno).

\begin{tabular}{|c|c|c|c|c|}
\hline & $\begin{array}{c}\text { Total } \\
\mathrm{N}=20\end{array}$ & $\begin{array}{c}\mathrm{M} \\
\mathrm{N}=13\end{array}$ & $\begin{array}{c}\mathrm{S} \\
\mathrm{N}=7\end{array}$ & $\mathrm{P}$ \\
\hline $\mathrm{Q} / \mathrm{P} 1$ & & & & 0.524 \\
\hline 1 & 0 & 0 & 0 & \\
\hline 2 & 0 & 0 & 0 & \\
\hline 3 & $4(20.0)$ & $2(15.4)$ & $2(28.6)$ & \\
\hline 4 & $13(65.0)$ & $8(61.5)$ & $5(71.4)$ & \\
\hline 5 & $3(15.0)$ & $3(23.1)$ & $0(0.0)$ & \\
\hline $\mathrm{Q} / \mathrm{P} 2$ & & & & 0.22 \\
\hline 1 & $1(5.0)$ & $1(7.7)$ & $0(0.0)$ & \\
\hline 3 & $1(5.0)$ & $1(7.7)$ & $0(0.0)$ & \\
\hline 4 & $6(30.0)$ & $2(15.4)$ & $4(57.1)$ & \\
\hline 5 & $12(60.0)$ & $9(69.2)$ & $3(42.9)$ & \\
\hline $\mathrm{Q} / \mathrm{P} 3$ & & & & 0.915 \\
\hline 1 & $1(5.0)$ & $1(7.7)$ & $0(0.0)$ & \\
\hline 2 & $1(5.0)$ & $1(7.7)$ & $0(0.0)$ & \\
\hline 3 & $2(10.0)$ & $2(15.4)$ & $0(0.0)$ & \\
\hline 4 & $11(55.0)$ & $6(46.2)$ & $5(71.4)$ & \\
\hline 5 & $5(25.0)$ & $3(23.1)$ & $2(28.6)$ & \\
\hline $\mathrm{Q} / \mathrm{P} 4$ & & & & 1 \\
\hline 1 & 0 & 0 & 0 & \\
\hline 2 & 0 & 0 & 0 & \\
\hline 3 & $5(25.0)$ & $3(23.1)$ & $2(28.6)$ & \\
\hline 4 & $4(20.0)$ & $3(23.1)$ & $1(14.3)$ & \\
\hline 5 & $11(55.0)$ & $7(53.8)$ & $4(57.1)$ & \\
\hline $\mathrm{Q} / \mathrm{P} 5$ & & & & 0.951 \\
\hline 1 & $2(10.0)$ & $2(15.4)$ & $0(0.0)$ & \\
\hline 2 & $2(10.0)$ & $1(7.7)$ & $1(14.3)$ & \\
\hline 3 & $6(30.0)$ & $4(30.8)$ & $2(28.6)$ & \\
\hline 4 & $3(15.0)$ & $2(15.4)$ & $1(14.3)$ & \\
\hline 5 & $7(35.0)$ & $4(30.8)$ & $3(42.9)$ & \\
\hline $\mathrm{Q} / \mathrm{P} 6$ & & & & 0.162 \\
\hline 1 & $2(10.0)$ & $2(15.4)$ & $0(0.0)$ & \\
\hline 2 & $1(5.0)$ & $0(0.0)$ & $1(14.3)$ & \\
\hline 3 & $4(20.0)$ & $1(7.7)$ & $3(42.9)$ & \\
\hline 4 & $7(35.0)$ & $5(38.5)$ & $2(28.6)$ & \\
\hline 5 & $6(30.0)$ & $5(38.5)$ & $1(14.3)$ & \\
\hline $\mathrm{Q} / \mathrm{P} 7$ & & & & 1 \\
\hline 1 & $5(25.0)$ & $3(23.1)$ & $2(28.6)$ & \\
\hline 2 & $4(20.0)$ & $3(23.1)$ & $1(14.3)$ & \\
\hline 3 & $8(40.0)$ & $5(38.5)$ & $3(42.9)$ & \\
\hline 4 & $1(5.0)$ & $1(7.7)$ & $0(0.0)$ & \\
\hline 5 & $2(10.0)$ & $1(7.7)$ & $1(14.3)$ & \\
\hline $\mathrm{Q} / \mathrm{P} 8$ & & & & 0.431 \\
\hline 1 & $1(5.0)$ & $1(7.7)$ & $0(0.0)$ & \\
\hline 2 & $1(5.0)$ & $0(0.0)$ & $1(14.3)$ & \\
\hline 3 & $5(25.0)$ & $2(15.4)$ & $3(42.9)$ & \\
\hline 4 & $5(25.0)$ & $4(30.8)$ & $1(14.3)$ & \\
\hline 5 & $8(40.0)$ & $6(46.2)$ & $2(28.6)$ & \\
\hline
\end{tabular}




\begin{tabular}{|c|c|c|c|c|}
\hline $\mathrm{Q} / \mathrm{P} 9$ & & & & 0.33 \\
\hline 1 & $5(25.0)$ & $3(23.1)$ & $2(28.6)$ & \\
\hline 2 & $4(20.0)$ & $2(15.4)$ & $2(28.6)$ & \\
\hline 3 & $5(25.0)$ & $5(38.5)$ & $0(0.0)$ & \\
\hline 4 & $3(15.0)$ & $2(15.4)$ & $1(14.3)$ & \\
\hline 5 & $3(15.0)$ & $1(7.7)$ & $2(28.6)$ & \\
\hline $\mathrm{Q} / \mathrm{P} 10$ & & & & 0.75 \\
\hline 1 & $2(10.0)$ & $2(15.4)$ & $0(0.0)$ & \\
\hline 2 & $2(10.0)$ & $1(7.7)$ & $1(14.3)$ & \\
\hline 3 & $12(60.0)$ & $7(53.8)$ & $5(71.4)$ & \\
\hline 4 & $2(10.0)$ & $2(15.4)$ & $0(0.0)$ & \\
\hline 5 & $2(10.0)$ & $1(7.7)$ & $1(14.3)$ & \\
\hline $\mathrm{Q} / \mathrm{P} 11$ & & & & 0.603 \\
\hline 1 & 0 & 0 & 0 & \\
\hline 2 & $2(10.0)$ & $2(15.4)$ & $0(0.0)$ & \\
\hline 3 & $4(20.0)$ & $3(23.1)$ & $1(14.3)$ & \\
\hline 4 & $7(35.0)$ & $5(38.5)$ & $2(28.6)$ & \\
\hline 5 & $7(35.0)$ & $3(23.1)$ & $4(57.1)$ & \\
\hline $\mathrm{Q} / \mathrm{P} 12$ & & & & 0.209 \\
\hline 1 & $1(5.0)$ & $1(7.7)$ & $0(0.0)$ & \\
\hline 2 & $3(15.0)$ & $3(23.1)$ & $0(0.0)$ & \\
\hline 3 & $6(30.0)$ & $5(38.5)$ & $1(14.3)$ & \\
\hline 4 & $4(20.0)$ & $1(7.7)$ & $3(42.9)$ & \\
\hline 5 & $6(30.0)$ & $3(23.1)$ & 3 (42.9) & \\
\hline $\mathrm{Q} / \mathrm{P} 13$ & & & & 0.218 \\
\hline 1 & $1(5.0)$ & $0(0.0)$ & $1(14.3)$ & \\
\hline 2 & $2(10.0)$ & $1(7.7)$ & $1(14.3)$ & \\
\hline 3 & $2(10.0)$ & $2(15.4)$ & $0(0.0)$ & \\
\hline 4 & $11(55.0)$ & $6(46.2)$ & $5(71.4)$ & \\
\hline 5 & $4(20.0)$ & $4(30.8)$ & $0(0.0)$ & \\
\hline $\mathrm{Q} / \mathrm{P} 14$ & & & & 1 \\
\hline 1 & $1(5.0)$ & $1(7.7)$ & $0(0.0)$ & \\
\hline 2 & $1(5.0)$ & $1(7.7)$ & $0(0.0)$ & \\
\hline 3 & $4(20.0)$ & $3(23.1)$ & $1(14.3)$ & \\
\hline 4 & $9(45.0)$ & $5(38.5)$ & $4(57.1)$ & \\
\hline 5 & $5(25.0)$ & $3(23.1)$ & $2(28.6)$ & \\
\hline $\mathrm{Q} / \mathrm{P} 15$ & & & & 0.344 \\
\hline 1 & 0 & 0 & 0 & \\
\hline 2 & 0 & 0 & 0 & \\
\hline 3 & $7(35.0)$ & $4(30.8)$ & 3 (42.9) & \\
\hline 4 & $9(45.0)$ & $5(38.5)$ & $4(57.1)$ & \\
\hline 5 & $4(20.0)$ & $4(30.8)$ & $0(0.0)$ & \\
\hline $\mathrm{Q} / \mathrm{P} 16$ & & & & 0.855 \\
\hline 1 & $3(15.0)$ & $2(15.4)$ & $1(14.3)$ & \\
\hline 2 & $1(5.0)$ & $0(0.0)$ & $1(14.3)$ & \\
\hline 3 & $6(30.0)$ & $4(30.8)$ & $2(28.6)$ & \\
\hline 4 & $6(30.0)$ & $4(30.8)$ & $2(28.6)$ & \\
\hline 5 & $4(20.0)$ & $3(23.1)$ & $1(14.3)$ & \\
\hline
\end{tabular}

Data are frequencies (\%)/Os dados são frequências (\%)

Q/P: Question/Pergunta; Numbers below Q/P represent Likert scale intervals/ Números abaixo de Q/P representam intervalos de escala de Likert 


\section{Conclusions}

These results can help researchers and practitioners to understand the holistic and broad IFS/BRC systems and diagnose the limitations of their own production processes. To verify the results, future research will be extended to other areas from diverse food sectors.

A main conclusion to be drawn from this study is that there is not a different opinion on worth about IFS/BRC between the surveyed industries according to their size that should be considered by food companies that seek to implement both systems effectively. According with the present study, and after adjusting to the limited sample size that we had on the Canary Islands, half the companies that participated in this study that work in the agrifood sector have implemented the IFS food safety management system, while the other half has another similar certification (ISO 22000, ISO 9001, etc.). These results seem to indicate the advance of implementation of quality certificates in Canarian agrifood industries in the last 10 years.

The conclusions are summarised below:

1- Companies with the IFS consider that the costs correspond to the benefits obtained.

2- Companies with the IFS perceive that communication and information are excellent.

3- Companies with the IFS consider that auditors' expertise and effectiveness are excellent.

4- Companies' degree of satisfaction with the IFS is generally high.

5- Companies without the IFS have sufficient knowledge about what the IFS certification consists of.

6- Companies without the IFS are in favour of implementing quality and food safety certificates.

7- Companies without the IFS believe that the IFS has more advantages than disadvantages. Some advantages include improved food safety and it being a very practical system. They emphasise some disadvantages, e.g., it is too expensive and its excessive bureaucratic burden.

8- Companies without the IFS generally consider other similar certificates that are less costly.

9- The size of companies is not decisive to implement the IFS.

These results were obtained from agrifood companies on the Canary Islands, whose production and structural characteristics can different vastly to other countries. However for the GFSI, certification requirements and their food safety parameters must be the same in all the industries subject to this certification.

\section{Conclusões}

Estes resultados podem ajudar os investigadores e os profissionais a compreender os holísticos e amplos sistemas IFS/BRC e diagnosticar as limitações dos seus próprios processos de produção. Para verificar os resultados, a investigação futura será estendida a outras áreas de diversos sectores alimentares.

Uma conclusão principal a ser extraída deste estudo é que não há uma opinião diferente sobre o valor do IFS/ $\mathrm{BRC}$ entre as indústrias investigadas de acordo com seu tamanho, que deve ser considerado por empresas alimentares que procuram implementar ambos os sistemas de forma eficaz. De acordo com o presente estudo e depois de se ajustar ao tamanho de amostra limitado que tivemos nas ilhas Canárias, metade das empresas que participantes e inseridas no sector agroalimentar, implementaram o sistema de gestão de segurança alimentar IFS, enquanto a outra metade tem outro certificação similar (ISO 22000, ISO 9001, etc.). Estes resultados parecem indicar o avanço da implementação de certificados de qualidade nas indústrias agroalimentares nas Canárias, nos últimos 10 anos.

As conclusões estão resumidas em seguida:

1- As empresas com IFS consideram que os custos correspondem aos benefícios obtidos.

2- As empresas com IFS presumem que a comunicação e a informação são excelentes.

3- As empresas com o IFS consideram que a experiência e a eficácia dos auditores são excelentes.

4- O grau de satisfação das empresas com o IFS é geralmente elevado.

5- As empresas sem IFS têm conhecimento suficiente sobre o que a certificação IFS consiste.

6- As empresas sem IFS são favoráveis à implementação de certificados de qualidade e segurança alimentar.

7- Empresas sem o IFS acreditam que o IFS tem mais vantagens do que desvantagens. Algumas vantagens incluem a segurança alimentar melhorada e o facto de se tratar de um sistema muito prático. São enfatizadas algumas desvantagens, por exemplo, é muito caro e a sua carga burocrática é excessiva.

8- As empresas sem o IFS geralmente consideram outros certificados similares que são menos onerosos.

9- O tamanho das empresas não é decisivo para implementar o IFS.

Estes resultados foram obtidos de empresas agroalimentares das Ilhas Canárias, cujas características de produção e estruturais podem variar muito em outros países. No entanto, para o GFSI, os requisitos de certificação e os seus requisitos de segurança alimentar 


\section{Conflict of interests}

The authors declare that there are no financial and/or personal relationships that could be viewed as presenting a potential conflict of interests. devem ser os mesmos em todas as indústrias sujeitas a esta certificação.

\section{Conflito de Interesses}

Os autores declaram não existir quaisquer relações de natureza pessoal ou Financeira que possam configurar um potencial conflito de interesses.

\section{References/ Referências}

1. Manoj D, et al. Operational performance and critical success factors of lean manufacturing in European food processing SMEs. Trends in Food Science \& Technology, 2013, vol. 31, no 2, p. 156-164.

2. García-Pérez AM, Chinea-Martín A. La actividad agroalimentaria en Canarias. Un enfoque de cadena de suministro. In: Fundación FYDE-CajaCanarias, editors. Tenerife, Spain; 2012. p. 25-33

3. Rodríguez-Domínguez C Felipe-Martell CA. (cited 2013 screens). in: URL: https://riull.ull.es/xmlui/bitstream/handle/915/832/La+Economia+de+Exp ortacion+de+las+Islas+Canarias.pdf;jsessionid=42A8B39B56555730CE83F0A96E89C9C2?sequence=1 p. 7-8

4. Asociación Industrial de Canarias, (ASINCA): cited 2017 screens). in: URL: http://www.asinca.es/tacgestorcontenidos_asinca_regional/modules. php? $\bmod =$ portal\&file $=$ index.

5. IFS International Featured Standars: cited 2017 screens). in: URL: https://www.ifs-certification.com/index.php/en/standards/251-ifs-food-en.

6. Schulze, Holger, et al. Heterogeneity in the evaluation of quality assurance systems: the International Food Standard (IFS) in European agribusiness. International Food and Agribusiness Management Review 11.3 (2008): 99-139.

7. McLeod S. Symple Spychology. Likert Scala: (cited 2008 screens). in: URL:. https://www.simplypsychology.org/likert-scale.html.

8. Le, S, et al. Awareness and perceptions of food safety of artisan cheese makers in Southwestern Ontario: A qualitative study. Food Control, 2014, vol. 41, p. 158-167.

9. R Core Team. R: A language and environment for statistical computing. R Foundation for Statistical Computing, Vienna, Austria. 2016. URL https:// www.R-project.org/.

10. Fitzgerald, A. I., Storer, CE., Bent, M J M. Impediments to adoption of on-farm quality assurance. En Proceeding of the 12th International Farm Management Congress (IFMA 99), July. 1999. p. 18-24

11. Böcker, A., Bredahl, M. E., Northen, J: ISO 9001 certification in British agribusiness: Motivations and performance impacts. In: Schiefer, G., Rickert, U. (Eds.): Quality Assurance, Risk Management and Environmental Control in Agriculture and Food Supply Networks. Proceedings of the 82nd Seminar of the European Association of Agricultural Economists (EAAE), University of Bonn, Bonn, Germany, 2004. 51-60.

12. Mensah, LD, Julien D. Implementation of food safety management systems in the UK. Food Control, 2011, vol. 22, no 8, p. 1216-1225.

13. Trienekens J and Zuurbier P. Quality and safety standards in the food industry, developments and challenges. International Journal of Production Economics, 2008, Vol. 113, Issue 1, 107-122. 